Katarina O. Lazić ${ }^{*}$

https://doi.org/10.18485/analiff.2018.30.1.10

Univerzitet u Beogradu

811.111'276.6:630

Šumarski fakultet

811.163.41'276.6:630

Originalni naučni rad

Primljen: 11.10.2017.

Prihvaćen: 23.05.2018.

\title{
EVIDENTIALITY AND MODALITY IN ENGLISH AND SERBIAN ACADEMIC DISCOURSE OF FORESTRY RESEARCH PAPERS
}

The aim of this paper is to investigate the relationship between evidentiality and epistemic modality in English and Serbian academic discourse of scientific articles in the field of forestry. Two corpora consisting of scientific texts in each of the two languages were formed and examples of evidentiality and epistemic modality were recorded in them. The findings and descriptions of evidentiality are presented comparatively, and the general finding is that the two languages generally express evidentiality through similar means. Some interesting constructions and differences in the use of evidential markers were described, such as two-layered evidentiality in English and evidential constructions with the verb moć $i$ 'can' and verbs of cognition in Serbian. The established purpose of these constructions is hedging, as one of the typical features of academic discourse. Another feature of the Serbian texts is a range of verbs of perception, while zero evidentiality appears in the English corpus only. The research suggests that the same linguistic means can be used as markers of evidentiality and epistemic modality, whose degree of epistemic evaluation varies depending on the type of information source and the evidential marker used. The epistemic component in evidentials is seen as facultative, while its degree varies along a gradient. Although evidentiality and epistemic modality deal with different semantic areas, a common overlap between them was found. However, it is proposed that demarcation between these two areas be maintained, despite the common overlap of these two areas in markers which only seem to be purely evidential at first sight.

Key words: evidentiality, epistemic modality, evidential markers, academic discourse

Univerzitet u Beogradu Šumarski fakultet, Kneza Višeslava 1, 11000 Beograd; elektronska pošta autora: katarina.lazic@sfb.bg.ac.rs 


\section{Introduction}

Given that one of the most interesting problems that researchers of modality are faced with is the relationship between evidentiality, i.e. marking of the source of information, and epistemic modality ${ }^{l}$, this paper is an attempt to comparatively examine the status of evidentiality in English and Serbian academic discourse of forestry research papers.

The research was conducted by observing markers of evidentiality in an English language corpus composed of ten scientific papers in the field of Forestry from ten different SCI ${ }^{2}$ list scientific journals and a book on the topic of forest ecology, whereas the Serbian corpus involved ten different articles from two different issues of the journal Bulletin of the Faculty of Forestry in Belgrade ${ }^{3}$ written by ten different authors. So far, there have not been many studies concerned with the theoretical status of evidentiality or its description in the Serbian language, which was an additional reason to write this paper. The description of evidentiality is provided using examples from the Serbian and English texts, while special attention is paid to certain adverbs, verbs of perception and some evidential constructions. The markers of evidentiality are subsequently classified as inferential or reportive and discussed, particularly with respect to the relationship between evidentiality and epistemic modality incorporated in the semantics of some of them.

The literature review defines the areas of epistemic modality and evidentiality and gives an overview of the theoretical dispute concerning these two areas. This section also points to certain studies whose findings are relevant for this research. The subsequent section presents the findings and descriptions of evidentiality in Serbian and English, which are grouped and presented comparatively. Each section with illustrative examples is followed by a short discussion on the findings. The author finds the connection between the findings and literature, and based on that reaches some conclusions on the complex relationship between evidentiality and

1 This research is confined to the complex relationship between epistemic modality and evidentiality, and makes no mention of deontic modality.

2 Science Citation Index - Journal list

3 Glasnik Šumarskog fakulteta. Univerzitet u Beogradu -Šumarski fakultetBeograd. 
epistemic modality. In addition, the paper highlights some specific features of academic discourse related to evidentiality.

Finally, the findings of this research can contribute to the debate on the relationship between epistemic modality and evidentiality. Although some researchers argue that they constitute the same area of epistemic modality, others believe that their demarcation is necessary because of the actually different semantic areas that they cover.

Most examples found in this research reveal that evidential markers incorporate epistemic modality as part of their semantics, unlike some other examples which are purely evidential. The overlap between the areas of evidentiality and epistemic modality in some of the examples is elaborated on and the author tries to provide some explanations for such coincidences. Eventually, it is argued that semantic demarcation between these two areas should be maintained and that the facultative incorporated epistemic component in evidential markers can move along a gradient, depending on the type of evidential marker and the information source, which can be either specified or unspecified.

\section{Literature review and related research}

This section of the paper introduces several topics that are connected with this research and presents a brief overview of different studies whose findings had an impact on the author and the conclusions reached in this paper.

\subsection{Hedging, citing and referencing as features of academic writing}

It is often believed that academic writing, particularly scientific writing, is factual, and that it simply conveys facts and information. However, it has been recognised that an important feature of academic writing is the concept of cautious language, often called "hedging" (Bowker, 2007). In other words, it is necessary to make decisions about your stance on a particular subject, or the strength of the claims you are making. A wide range of words and phrases can be used in hedging and some of these are the following: modal auxiliary verbs such as can, could, may, might, should, would, verbs of perception such as appear, look, seem, tend, probability 
adjectives such as likely, possible, probable, unlikely, probability adverbs such asperhaps, possibly, probably, presumably, frequency adverbs such as generally, occasionally, often, seldom, usually, that clauses and a number of other constructions. A large number of words and phrases used in hedging are at the same time markers of evidentiality, which makes this feature of academic writing particularly interesting for this research.

Early research of Fraser (1975) investigated the effect of modals and semi-modals on the illocutionary act denoted by a performative verb in performative sentences. He found that the modal relieves the speaker from some of the responsibility, and calls such cases 'hedged performatives'. In some of his later researches Fraser (1980) also discusses hedging as the mitigation of the force of harshness and hostility of one's actions, limiting hedges to expressions like kind of and sort of.

House and Kasper (1981) have also discussed hedges as a means of modifying certain types of speech-acts, i.e. requests and apologies. They created a politeness marker category called downgraders in which they included hedging. In their paper these devices are called hedges, understaters, down toners, play-downs or minus staters.

On the other hand, Hyland (1998) describes hedging as "either a lack of complete commitment to the truth value of an accompanying proposition or a desire not to express that commitment categorically" (p.1). In his book on hedging in scientific articles this author relates a systematic analysis of forms to a pragmatic explanation and provides a comprehensive study of hedging in academic research papers. The study shows connection between the extensive use of possibility in research writing and the social and institutional practices of academic communities, as well as the ways knowledge is socially accepted through texts. Major functions, forms and distribution of hedges are identified and research article genre is investigated to present a framework based on the ideological and social environment that interprets academic texts. The conclusion is that hedging is crucial for making scientific arguments and science in generall. In addition to that, Hyland elaborates on the importance of hedging for student writing with certain teaching implications related to the use of hedging.

The use of literature to support your ideas is one of the primary features of academic writing. This requires that the authors read widely the work of other reseasrchers, in order to seek out the different sides of a 
debate within a particular field of inquiry. This also means that the authors need to demonstrate evidence of their literature exploration by including these researchers in their writing and mentioning their points of view. This technique of referring to other authors is often termed citing, documenting, or in-text referencing. This kind of information is useful in that it provides evidence, which may be in the form of theoretical ideas, critical evaluations, research findings, and scholarly opinions to back up the points you are making (Bowker, 2007). All cases of citing and referencing mark the source of information for the given statements, which makes them markers of evidentiality. The academic discourses of Serbian and English, which are investigated in this research, reveal their specific features of evidentiality through citing, referencing and hedging.

\subsection{The relationship between evidentiality and epistemic modality}

Evidentiality may be defined in functional terms as the speaker's assessment of his/ her grounds for saying what he/she does, and an evidential as a grammatical form which expresses evidentiality (Portner, 2009).

Great care must be taken in considering the relationship between evidentiality and epistemic modality, as different scholars talk about it in different ways. The following two views can be found in the literature which attempts to give a precise analysis of evidentiality: Evidentiality should be distinguished from epistemic modality because the two categories relate to quite different types of meaning. Evidentials affect the speech act performed by a sentence (i.e. its sentential force), while epistemic modals contribute to truth conditions just as claimed by modal logics (Portner, 2009). De Haan (1999) claims that the two notions should be distinguished because there are major differences between the two. He argues that evidentiality and epistemic modality differ in their semantics, i.e. that evidentials assert the nature of the evidence for the information in the sentence, while epistemic modals evaluate the speaker's commitment to the statement. He also claims that the origins of evidential morphemes differ greatly from the lexical sources of epistemic modals.

Alexandra Aikhenwald (2004), who investigated evidentiality in many different languages, holds that although every language has lexical and other means to denote the source of information, only about one 
quarter of the languages of the world have it as a grammatical category. Aikhenvald (2004) notes that in many languages evidential systems are frequently marked in parallel with other linguistic categories. For example, a given language may use the same element to mark both evidentiality and mirativity. Although Aikhenvald (2003) argues that evidentials may indicate the attitude of the speaker about the validity of a statement, she believes that is not a required feature of evidentials, and holds that evidential-marking and epistemic-marking can cooccur. When the relationship between evidentiality and modality is concerned, Aikhenvald (2004) quite vigorously argues that these are two different categories, and the central argument is that when the information source is marked as a grammatical category it still does not imply any reference to the validity or reliability of knowledge or information. This author also argues that evidentiality and epistemic modality are two different categories because they are mutually exclusive in a number of languages.

On the other hand, Plungian (2001) argues that there is a domain where modal values and evidentials overlap, and where probability is evaluated. According to him, an epistemic marker contains more evidential properties in the case of a specified source of the speaker's hypothesis. An evidential supplement can always be seen in an epistemic marker, while the opposite is not always true. Actually, not all evidential markers are modal since they do not necessarily include an epistemic judgement. This author argues that, generally, reliability of information mostly depends on the way it was obtained, i.e. that mediated information is considered the least reliable, while visually obtained information seem to be the most reliable. More precisely, this author pointed out that some kind of knowledge is always related to epistemic judgments, but that epistemic evaluation is not always involved, as in the case of hearsay. There is an inversion of the relationship between epistemic modality and evidentiality in that case, since it seems as if epistemic meanings depend on evidential ones.

Some other authors argue that evidentiality is a kind of epistemic modality, since evidential crucially contribute to truth conditions (McCready, Ogata and Matthewson in Portner, 2009). These authors are actually proposing that evidentiality and epistemic modality together constitute a broader class, and that, within this class, epistemic modals and evidentials are two common types. 
Many scholars believe the relation between these two categories is a strong one (or even a necessary one). For example, Palmer (1986: 51) divides the realm of epistemic modality in the following way:

"There are at least four ways in which a speaker may indicate that he is not presenting what he is saying as a fact, but rather:

(i) that he is speculating about it

(ii) that he is presenting it as a deduction

(iii) that he has been told about it

(iv) that it is a matter only of appearance, based on the evidence of (possibly fallible) senses."

The area of possibility (i) is commonly called jugd(e)ments and is what people usually associate with epistemic modality. The other three possibilities represent three types of evidentiality. What binds these four possibilities together, according to Palmer (1986) is: “... the indication by the speaker of his (lack of) commitment to the truth of the proposition being expressed" (p. 51).

Palmer (1986) differentiates between two different subsystems of epistemic modality the subsystem of judgments with speculatives and deductives as its members and evidentials whose members are quotatives (which are used to quote someone else's words) and statements whose source is sensory evidence.

According to the Palmer's 1986 language typology both languages investigated in this research, i.e. English and Serbian belong to the languages with a subsystem of evidentials which tends to be marked through a variety of elements indicating the information sources which are optional and usually do not indicate evidentiality as their primary function - thus do not form a grammatical category.

Trbojević-Milošević (2004) provides a contrastive description of epistemic modality in Serbian and English, in which evidentiality is placed within the wider scope of epistemic modality. However, she pays particular attention to some, although not all modal markers with specific evidential semantics. Researchers of evidentiality as a specific semantic category, which can be grammaticalised or expressed through lexical means, have agreed that epistemic meaning is present in only one group of evidentials. According to Vjemer in Popović (2010), who investigated the share of epistemic modality in the structure of evidential markers, the epistemic 
component in evidential markers occurs primarily in the statements which are reported words of another person, in the cases where the speaker explicitly expresses his/her evaluation of the truthfulness of the information obtained second-hand. In the case of inferential modality modal words take over the role of evidential markers and they refer more to the way of perceptive or logical deduction or the origin of the proposition than to the judgement of its truthfulness. This paper only partly supports that view and elaborates on some examples of inferential evidentiality which incorporate epistemic meaning, and that will be discussed into detail in the subsequent sections.

As far as terminology is concerned, it was observed that Popović (2010), who investigated the relationship between modality and evidentiality in Serbian and Ukrainian, used Vjemer's term reportive evidentiality to indicate that the information was reported to the speaker by another person. The same author uses the term inferential evidentiality to refer to the way of logical deduction used to get to the information which is being conveyed. Some of the types and subtypes of this typology will be used in the description of evidential markers in this paper.

\section{Materials and method}

This research was performed by observing and recording the examples of markers of evidentiality in an English language corpus composed

of ten scientific papers of approximately ten thousand words in the field of Forestry from ten different SCI list scientific journals and one book on the topic of forest ecology, whereas the Serbian corpus included ten articles with an approximate number of words from two different issues of the journal Bulletin of the Faculty of Forestry in Belgrade.

For the English texts names of authors and their affiliate institutions were used to make sure that the articles were written by native English speakers. In addition, in order to avoid idiosyncrasies from individual writers, the author of this research made sure that the investigated texts in both Serbian and English come from different authors. The observed examples of evidentiality were extracted and they are discussed into more detail in the following section. 
The results are listed and discussed in three major subsections including reportive, inferential and zero evidentiality, with special attention paid to some interesting examples of evidentiality subtypes and adverbs with specific semantics.

\section{Results and Discussion}

\subsection{Reportive evidentiality in Serbian and English academic discourse}

Some of the major features of the academic discourse are citing and referencing, which are typical examples of reportive evidentiality with a specified source of information. They appear in a variety of forms such as in the following expressions in Serbian:

Expressions with a specified source of information:

(1) Učešce devastiranih sastojina u kitnjakovim šumama je visoko (Medarević, 2006). 'The share of devastated stands in sessile oak forests is high' (Medarević, 2006).

(2) Grini (Greene, 1998) kao načine promocije navodi... 'as ways of promotion Greene (1998) states'

Sometimes they occurr in the form of double referencing, such as in:

(3) Prema Srejoviću (Medarević et al. 1991), klima mezoklisura je svežija.'According to Srejović (Medarević et al, 1991) the climate of meso gorges is cooler.'

Similar examples were found in the English text:

(4) ...one year ground water travel time (cf.Pijanowski and others, 2007)

(5) As argued by Marsalek and others (2001), they have not been the subject of systematic research.

(6) The relationship between morphology and survival is not linear as shown by Oliet et al. (2009).

About $20 \%$ of all the recorded examples of evidentiality in the Serbian text and about $25 \%$ in the English text belong to citing and referencing. 
These findings indicate that the percentage of reportive evidentiality with a specified source of information in the Academic discourse and the corpus of forestry is high when compared to other types of evidentiality. Both texts generally reveal a lot of evidential marking of all types. These findings are also fully in accordance with the style of academic writing which imposes upon the writer the obligation to support his statements with a specified source of information in the form of referencing and citing.

There are also examples of expressions with a less specified source of information such as in:

(7) Prema navodima iz zapadne Evrope, u lišćarskim šumama je ona fakultativni parazit. 'According to some records from Western Europe it is a facultative parasite in broadleaved forests.'

(8) Neki istraživači napominju da se u Finskoj i Škotskoj ova vrsta često sreće kao izazivač truleži. 'Some researchers note that this species is a common cause of wood rot in Finland and Scotland.'

(9) Francuski autori su ustanovili da je Quercus borealis osetljiv na napad gljivica.' 'French authors found that Quercus borealis was sensitive to wood rotting fungi attack.'

(10) Ranija istraživanja pokazuju da konkurentnost cena pored kvaliteta utiče $n a$...'Previous research has shown that, besides quality, the competitiveness of prices affects...'

(11) Autori su zaključili da je patogenost A. mellea i A.ostyae približno ista.'The authors have concluded that $A$. mellea and A.ostyae are characterized by almost the same pathogenicity.'

Examples of autoreferencing were found in both the English and the Serbian corpus, such as in:

(12) Kao što smo već napomenuli, potencijal šumskog porekla biomase pruža osnovu za njeno ekonomski opravdano korišćenje.'As we had already mentioned in this paper, the potential of the origin of biomass from forests provides the basis for its economically justified use.'

Another example from the English text is illustrative of autoreferencing:

(13) As we have already suggested, these weights incorporate human values. 
One of the typical examples of autoreferencing which is commonly found in Serbian discourse kao što sam ranije rekao 'as I have already said' (Popović, 2010) appears in a slightly different form in the Serbian corpus of this research in the form kao što smo već napomenuli 'as we have already noted', and in the English corpus as the closely corresponding form as we have already suggested. In both cases the actual speaker coincides with the primary speaker, who is a specified speaker, which adds epistemic meaning.

In some of the examples the source of information is not specified, such as in:

(14) U ovoj studiji je ustanovljeno da su šume bukve, jele i smrče slične po učě̌ću flornih elemenata. 'In this study it was established that beech, fir and spruce forests are similar in terms of the share of floral elements.'

(15) U diskusiji za NPVse napominje da postoji dosta mogućnosti za smanjenje... 'In the discussion it was noted that there were plenty of options for reduction...'

(16) Analizom uslova konstatovano je da postoje poslovne banke kod kojih je moguce dobiti kredit sa kamatnom stopom od 5\%. 'In the analysis of conditions it was found that there are some banks that provide loans with a $5 \%$ interest rate.'

(17) Ovim istraživanjem je i sa aspekta finansija potvrđeno da se dobri rezultati $u$ intenzivnim zasadima mogu očekivati, iako se oni ne nalaze na optimalnim staništima. 'In this research it has also been confirmed from the financial aspect that good results can be expected in intensive plantations, in spite of the fact that they cannot be found in optimal sites.'

Some authors, such as De Haan (1999) argue that demarcation between epistemic modality and evidentiality is necessary, because an evidential asserts that there is evidence for the speaker's utterance, but refuses to interpret the evidence in any way and epistemic modality reflects the degree of confidence in the truthfulness of the statement. However, in a paper which compares modality and evidentiality in Serbian and Ukrainian, Popović (2010) argues that the same marker can both have a modal function and express evidentiality. According to her, the epistemic component of the same markers varies from neutral to negative evaluation of the truthfulness of a statement and this epistemic component is facultative. Depending on whether the source of information is specified or unspecified the amount of epistemic modality can vary if the same marker is used. 
The author argues that evidential markers have epistemic modal meaning in the cases where the source of primary information is a concrete speaker. It is also argued that the cases with an unspecified source of information are epistemically neutral.

If we take a look at some of the examples from this paper, we can argue that when the writer marks a concrete person as the source of information, such as in (1) or (2), he does not take on any responsibility for the truthfulness of the statement, which makes his attitude neutral. On the other hand, if we look at the expressions with an unspecified source of information such as (14) ustanovljeno je 'it was established' and (16) konstatovano je 'it was established/found' the idea may be that the information comes from a source which is generally acceptable as reliable, which slightly evaluates the statement, implying that the speaker/writer shows a positive attitude towards logical deduction used as the source of this statement. The first finding does not corroborate the findings of Popović (2010), who argued that evidential markers with a specified source of information incorporate a high degree of evaluation of the truthfulness of the proposition, which makes them burdened with epistemic meaning. The same author claims that when the source of information is not specified, the speaker's attitude towards the truthfulness of the statement is neutral. Unlike Popović (2010), we argue that some indirect evaluation of the truthfulness of these statements is incorporated in such expressions.

Some examples of the evidential modal adverb reportedly were recorded in the English corpus, as well as some examples of reportive evidentiality with an unspecified source of information such as is said to.

Two examples of the evidential modal adverb reportedly were found with no closely corresponding adverb in the Serbian corpus.

(18) Heather voles reportedly used kinnikinnick as 85-90 per cent of their diet in both summer and winter.

(19) Oysters reportedly can discharge 500 million ripe eggs.

An example of reportive evidentiality with an unspecified source of information, in the form of an evidential phrase is said to was also found, which is illustrated by the example

(20) Queen termites are said to lay tens of thousands of eggs. 
Both these examples involve epistemic markers with an unspecified source of information. If we use the same logics as in the previous paragraph, that an unspecified source can be regarded as generally acceptable, they may be seen as expressions with a slightly positive and not neutral attitude towards the truthfulness of the reported statements.

Some authors have argued that the nature of evidentials is heterogenous and that the same markers denote evidentiality and epistemic modality, and especially that the degree of epistemic modality can move along an epistemic gradient (Vjemer in Popović, 2010). Findings of the research Popović (2010) suggest that the same markers can have both the modal and evidential function depending on the situation and context and the marker's place in a sentence. Popović (2010) argued that the Serbian evidential marker navodno 'allegidlly' in some, but not all cases, clearly indicates distancing from the truthfulness of the proposition, or even doubt in its truthfulness, which makes it heavily burdend with epistemic meaning.

This research is confined to academic discourse, and probably because of that many interesting examples of reportive evidentials, such as allegedly were not found in the English discourse. This adjective is mentioned in the section on reportive evidentiality, because it is semantically close to the adverb reportedly. The adjective allegidly, described by Trbojević-Milošević (2004), actually expresses lack of evidence and commonly occurs in texts related to trials investigations or other forms of legal action. The semantically close Serbian adjective navodno 'allegidly, 'which means "according to the words of others" is mentioned by Popović (2010) as an adjective whose position in a sentence defines the measure of its epistemic component. Trbojević-Milošević (2004) described navodno 'allegidly' as an adjective with a special semantic effect.

Both the English and the Serbian texts in this research are marked by the absence of such adjectives and the presence of semantically similar, but epistemically less distancing adjectives and phrases.

Finally, it can be concluded that the same linguistic means can be used as markers of evidentiality and epistemic modality and that the degree of epistemic evaluation in an evidential expression varies depending on the specific markers and types of information sources. 


\subsection{Inferential evidentiality in Serbian and English academic discourse}

Unlike in the case of reportive evidentiality, in which the source of information is someone elses statement, the source of information in inferential evidentiality is logical deduction. A number of verbs of cognition such as zaključiti 'conclude', konstatovati 'establish', utvrditi 'determine', ustanoviti 'find' and the conclusive verb ukazivati 'imply' illustrate this type of evidentiality in the Serbian text:

(21) Na osnovi svega izloženog, može se zaključiti da ne postoji uslov za proširenje materijalne osnove. 'On the basis of the above, it can be concluded that there is no grounds for expanding the material plan.'

(22) Na osnovu istraživanja u ovom radu, ustanovljeno je da su šume jele, bukve $i$ smrče po učešću sredenjeevropskih flornih elemenata slične svim navedenima.'On the basis of the research described in this paper, it was found that forests of fir, beech and spruce are similar in terms of the share of floral elements.'

(23) Prethodnim ispitivanjima utvrđeno je da izabrani lepak ne izaziva vidljive promene na premazu. 'Previous research had determined that the selected adhesive does not cause visible changes on the coating.'

(24) U kasnijim istraživanjima na Zlataru konstatuje se široko rasprostranjenje ove zajednice.' In further research on Mt.Zlatar it was established that the distribution of this community was wide.'

(25) Prikazani rezultati ukazuju na to da se u zasadima topola može izvoditi prilično sigurna računica. 'The shown results imply that fairly correct calculations can be made in poplar plantations.'

On the basis of the listed examples, it is obvious that it is sometimes difficult to keep the classification into reportive and inferential evidentiality without a certain overlap. Although the listed markers of evidentiality refer to the way of logical deduction, some of them, such as (23) and (24) at the same time report on deductions whose source is a statement from another investigation.

The verb zakljuciti 'conclude'such as in examples (21), (26) and (27) often occurs in a construction with the verb moć i 'can' such as in: 
(26) Možemo zaključiti da u zajednici jele bukve i smrčena Tari preovlađuju florni elementi hladnijih predela. 'We can conclude that floral elements of cold landscapes prevail in the community of fir, beech and spruce on Mt.Tara.'

(27) Kao što se može zaključiti interna stopa definiše povrat na investirani capital.'As it can be concluded the internal rate defines the return on invested capital.'

The verb moći 'can' in example (26) can be interpreted as a confirmation that logical deduction, which is the source of information, can take place. This adds a little bit of hedging to the statement, in comparison to a possible statement e.g.Stoga, zaključujemo da u zajednici jele $i$ smrče... 'Therefore, we conclude that in the community of fir and spruce...', which is fully in accordance with the style of academic writing.

In example (27) the listener is reminded of the fact that a similar way of deduction is generally acceptable, which adds justification to logical deduction. We can suppose that the writer assures the reader that there is a possibility to make a logical deduction, which is the guarantee for the truthfulness of that statement. As the writer reminds the reader that he/she approves of the logical deduction which leads to the statement, some indirect positive evaluation of its truthfulness can be recognized, but the writer is still distanced from explicitly expressing this attitude. It seems logical that these evidential markers appear in academic writing, whose language should present conclusions, which are open to further investigation, and not presented to the reader as the absolute truth.

In the English corpus we find some of the verbs such as suggest and indicate which refer to the way of logical deduction.

(28) Our finding suggests that results from further analysis of whole intra-ring mean densities might be difficult to use.

(29) Altogether, these results indicate it was the effects of treatment at the intraring level that were the most apparent.

There is also an example of two-layered evidentiality, such as in (30). The verb of perception seem is followed by the verb suggest in the second layer, which explains the way of logical deduction. It seems as if the speaker is trying to be cautiously distanced from the possibility that 
a certain way oflogical deduction is the right one. Once again the feature added to the text is hedging.

(30) The week trend observed in our study, however, seems to suggest that fertilization causes EW\% to reach a stable level.

The verb of perception seem was found in several examples in the English corpus, such as in:

(31) Furthermore, since the treatment had no effect in latewood densities, it seems that the fertilization treatments used in the present study did not lower wood density.

Although English does not have a grammaticalized system of evidentials, and belongs to the languages whose modal system is basically a system of judgements, some propositions are based onevidence available through perception. Such a statement is also placed into the category of epistemic judgements, and only some languages have separate systems of judgements and evidentials (Palmer, 1986). The most reliable of the senses is vision, although not completely reliable. Trbojević-Milošević (2004) describes the verbs seem and appear in a construction with infinitive. They imply that the evidence available through the sense of vision allows someone to conclude something. Therefore, they refer to the way of logical deduction as the source of information.

Yet, it seems that these verbs are not purely evidential and epistemically neutral since the verbs such as seem or appear express a certain amount of belief of the speaker in the truthfulness of the propositions from his/her own perspective, especially in constructions such as it seems to me that...Although evidentials are generally considered objective, Palmer (1986) wrote that it can only be concluded at first sight, because evidentials which introduce information received through visual or other senses must be subjective in their origin. According to him, they indicate that the speaker gives no guarantees for that truthfulness of the statements. However, although no guarantees can be made, the speaker presents his/ her own perspective, and a positive attitude towards the truthfulness of the statement can be recognized. As it can be seen from example (31), the phrase it seems that can be used to express epistemic modality and make a judgement of a past event in the present. 
Trbojević-Milošević (2004) describes the Serbian verbs izgledati 'appear'and činiti se 'seem' as evidentials, and Popović (2010) makes difference between the use of those verbs with a dative pronoun, which according to her then makes them reportive or inferential. It can be argued that they primarily indicate that perception is the basis for logical deduction, and they should be placed into the category of inferential evidentials. As they are highly subjective, some evaluation of the truthfulness of the statement following them has been recognized, i.e. an overlap between their evidential and epistemic components.

Verbs of perception which can be placed into the same semantic category as videti 'see', such as zapaziti 'notice',uočiti 'observe' and primetiti 'spot'were used in the Serbian text to denote inferential evidentiality.

(32) Zapaža se takođe da je zapremina materijala na lopatici promenljiva. 'It has also been noticed that the volume of material on the blade is changeable.'

(33) Uočava se, takođe, da je karakter krive drugačiji pri malim vrednostima u odnosu na krive za veće uglove. It can also be observed that the character of the curve at small values differs from the curve at greater angles.'

(34) Uvidom u dobijene podatke za internu stopu prinosa može se zapaziti da se njena vrednost kreće u rasponu od 4,32 do 6, 94\%.' On the basis of the insight into the results obtained for the internal yield rate, it can be noticed that its value ranges from 4,32 to $6,94 \%$.'

(35) Poslednjih godina može se primetiti da postoji nova ekološka etika, koja treba da se temelji na aktivnom odnosu...'In the past few years a new ecological ethics can be observed, which should be based on an active relationship.'

(36) Može se videti da je film kompaktan i da ne postoje oštećena mesta. 'It can be seen that the film is compact and undamaged.'

In all these examples with verbs of perception the source of information is unspecified and not concrete. Popović (2010) argues that quotatives with a specified source are more burdened with epistemic meaning than the expressions, in which the source of information is unspecified, which are according to her, epistemically neutral.

In the above examples the source of perception is not specified, and the origin of logical deduction is perception. However, it can be argued that the writer also indirectly expresses some belief in the truthfulness of the state- 
ment by drawing the attention of the reader to the fact that what is claimed can be percieved by many entities or generally. The writer's attitude towards the truthfulness of the statement is not clear, but his/her attitude towards logical deduction as the source of informationin this case is positive, which may indirectly also refer to the positive evaluation of the statement.

It is difficult to keep the classification into reportive and inferential evidential markers, as some of them denote that the source of logical deduction is perception which makes them inferential, but also that this deduction comes from another piece of writing.

Merlini-Barbaressi in Trbojević-Milošević (2004) classifies modal adverbs, apparently, clearly, evidently, obviously and manifestly as inferential adverbs. Accroding to her they do not indicate that the speaker's own attitude towards the epistemic status of the proposition, but that the listener should make a conclusion regarding the truthfulness of the proposition, and that the listener should conclude themselves on the truthfulness of the proposition on the basis of the available evidence. These adverbs are also called evidential adverbs based on the fact that they do not support modality, but evidentially submodify the epistemic system based on judgements (Hoye, 1997 in Trbojević- Milošević 2004). Some examples of these adverbs were found in the English text, and they are the following:

(37) Clearly, research is needed to improve valuation options for NEBA.

(38) Obviously, microclimatic conditions during summer periods are alternatively dry in IDF forests, and...

In addition, an evidential expression with a similar meaning was also found:

(39) In any case, it is evident in the present work that there is an overwhelming effect of morphological attributes over physiological and performance attributes.

This modal expression is semantically similar to the modal adverbs clearly and obviously, and similarly refers to logical deduction as the source of information. Therefore, it can also be placed into the category of inferential evidentials. However, it can be argued that there is a subjective component, which adds evaluation of the truthfulness of these statements. 
Something that may seem evident, clear or obvious to the speaker does not refer to others who may not realize the logics underlying the deduction in (37), (38) and (39). Therefore, it can be interpreted that these statements seem clear, obvious and evident from the perspective of the speaker who uses these very adjectives to show his/ her positive attitude towards the way of logical deduction. On the basis of that, we can say that they are subjective and show a kind of positive indirect evaluation of theproposition as well. A similar example was found in the Serbian text with the evidential marker očigledno 'obviously':

(40) Očigledno je da porast ugla postavljanja lopatice, a pri malim vrednostima ugla ne utiče značajno na količinu materijala.'Obviously, an increase in the angle

of the blade, at small angle values does not significantly affect the quantity of material.'

In the case of očigledno 'obviously', the speaker actually evaluates the logical deduction by saying that it is easy to make and believes that it is a valid source of information.

Finally, it has been generally accepted that these inferential evidentials primarily indicate that the source of information is logical deduction, and it can be added that they do not only assert the evidence but also positively evaluate the logical deduction and support the reader in making such a deduction.

\subsection{Zero evidentiality}

Zero evidentiality can be defined as an attempt to transfer a kind of direct personal experience to the listener or reader. Imperative can instigate the listener or reader to direct perception by activating one of the senses. Examples of zero evidentiality often do not contain modal markers. Popović (2010) suggests that the category of zero evidentiality should involve verbs of perception in the imperative mood.

Although no such examples were found in the Serbian corpus of this research, an interesting example was found in the English corpus.

(41) Note that prior to 1975 there is no treatment as these are historical years. 
In this example the writer does not overtly express his/her attitude toward the truthfulness of the statement, but asks the reader to experience the same inference through his/her own senses.

\section{Conclusions}

The aim of this paper was to investigate evidentiality and its relation to epistemic modality in academic forestry research papers in Serbian and English. Although both English and Serbian belong to the type of languages without a grammaticallised system of evidentials, they generally express evidentiality through similar means, and some minor differences in the use of their evidential markers were observed. However, most evidential forms in one of the two languages have closely corresponding markers in both their semantics and form in the other language.

The English corpus revealed presence of the reportive evidential adverb reportedly, while it was not possible to find an adverb in the Serbian corpus which would closely correspond to it in its semantics and form.

The Serbian corpus revealed a wider range of verbs of perception than the English corpus. These verbs are videti 'see', zapaziti 'notice', uociti 'observe' and primetiti 'spot', which implies that visual perception is the primary source of logical deduction. Further, the Serbian corpus revealed lack of zero evidentiality, whereas the English texts involved one interesting example of this evidentiality subtype, and both the English and Serbian texts showed the absence of adverbs with specific semantics, such as navodno'allegidly'.

Some conclusions were also reached regarding the specific features of academic discourse when evidentiality is concerned. The academic discourse investigated in this research reveals a high percentage of reportive evidential markers with a specified source of information in both the English and Serbian texts. This can be explained for by the fact that claims made in academic discourse are generally often supported by citing and referencing. In addition to that, hedging was observed as the function of a large number of evidential markers used in this discourse.

Some interesting constructions, such as two-layered evidentiality in the English corpus and evidential constructions with the verb moć $i^{\text {'can' }}$ 
and verbs of cognition were foundin the Serbian corpus. What is more, it was concluded that the purpose of these constructions is hedging, as one of the typical features of academic discourse.

It should be pointed out that the classification of evidentiality into reportive, inferential and zero evidentiality is not strict, as some evidential markers belong to more than one of these categories. The purpose of this classification was to group the markers of evidentiality, facilitate their description and observance of similarities and differences between them in the investigated languages.

The research of reportive evidentiality in this study indicates that when the source of information is specified, there is no evaluation of the statement. On the other hand, when the source of information is unspecified, some indirect positive evaluation can be observed, and therefore these cases are not seen as epistemically neutral.

Although it is generally believed that inferential evidentials are epistemically neutral, this paper presents the finding that several inferential evidential markers observed in this research positively evaluate the deduction taking place as the source of information, which may be seen as indirect support to the truthfulness of that statement.

In addition to that, the findings of this research can contribute to the debate on one of the most interesting issues that scholars of evidentiality are faced with, and that is the relationship between evidentiality and epistemic modality. While Palmer (1986) views all evidentials as subjective and part of a broader class of epistemic modality, De Haan (1999) believes that demarcation between evidentiality and epistemic modality is necessary, since evidentials are unmarked with respect to a commitment to the truth, while evidentials merely assert that there is evidence to back up the speaker's utterance. With reference to that, this research of English and Serbian academic discourse takes the intermediate position, in line with the view of Givon in De Haan (1999), who claims that the link between evidentiality and epistemic modality is not straightforward. In accordance with that, the research described here suggeststhat the same linguistic means can be used as markers of evidentiality and epistemic modality, whose degree of epistemic evaluation varies depending on the type of information source and the evidential marker used. Although evidentiality and epistemic modality deal with entirely different semantic areas, 
the findings of this research suggest that in most cases there is an overlap between them. Yet, in somecases the speaker's attitude towards the truthfulness of the statement is neutral and can be seen as purely evidential. On the basis of that, it is suggested that demarcation between these two areas should be maintained, but also that an overlap between them can occur in markers which only seem to be purely evidential at first sight. According to this research, the epistemic component in evidentials is seen as facultative and its degree can vary along a gradient.

Finally, it should be noted that this research is confined to the relationship between evidentiality and epistemic modality in Serbian and English academic forestry research papers. Future research could investigate the specific features of evidentiality in other types of discourse or a corpus of texts belonging to a different scientific discipline. Since zero evidentiality was observed in just one example in the English corpus, a more detailed research of this type of evidentiality in the academic discourses of both investigated languages could be another extension left to some future research.

\section{References}

Aikhenvald, A. Y. (2003). Evidentiality in typological perspective. In A. Y. Aikhenvald \& R. M. W. Dixon (Eds.) (pp. 33-62). Amsterdam: John Benjamins.

Aikhenvald, A.Y. (2004). Evidentiality. Oxford: Oxford University Press.

Bowker, N. (2007). Academic Writing: A Guide to Tertiary Level Writing. Massey University: Palmerston North.

De Haan, F. (1999). Evidentiality and epistemic modality: Setting boundaries. Southwest Journal of Linguistics, 18, 83-101. www.u.arizona.edu/ fdehaan/papers/SWJL99.pdf.

Fraser, B. (1975). Hedged Performatives. In Cole, P. and Morgan, J. L. (eds.), Syntax and Semantics. Vol. 3. (pp. 187-210). New York: Academic Press.

Fraser, B. (1980). Conversational Mitigation. Journal of Pragmatics. 4 (4), 341-350.

House, J. \& Kasper, G. (1981). Politeness markers in English and German. In F. Coulmas (Ed.), Conversational routine: Explorations in standardized communication situations and prepatterned speech. The Hague: Mouton.

Hyland, K. (1998). Hedging in scientific research articles. Amsterdam / Philadelphia: John Benjamins. 
Palmer, F.R. (1986). Mood and Modality. Cambridge: Cambridge University Press. Plungian, V. (2001). The place of evidentiality within the universal grammatical space. Journal of Pragmatics, 33, 349-357.

Popović, Lj. (2010). Kategorija evidencijalnosti u srpskom i ukrajinskom jeziku. Zbornik Matice srpske za slavistiku, 77, 17-47.

Portner, P. (2009). Modality. Oxford: Oxford Linguistics.

Trbojević-Milošević, I. (2004). Modalnost, sud, iskaz. Beograd: Filološki fakultet Beograd.

Katarina O. Lazić

\section{Sažetak}

\section{EVIDENCIJALNOST I MODALNOST U AKADEMSKOM DISKURSU ISTRAŽIVAČKIH ČLANAKA ŠUMARSTVA NA SRPSKOM I ENGLESKOM JEZIKU}

S obzirom na to da je jedan od najinteresantnijih problema sa kojim se suočavaju istraživači modalnosti veza između evidencijalnosti, odnosno označavanja izvora informacije, i epistemičke modalnosti, ovaj rad predstavlja pokušaj da se komparativno ispita status evidencijalnosti u engleskom i srpskom akademskom diskursu i korpusu šumarstva. Istraživanje je sprovedeno tako što su posmatrani markeri evidencijalnosti u korpusu tekstova na engleskom jeziku, koji se sastojao od naučnih članaka iz oblasti šumarstva iz časopisa sa SCI liste i knjige iz oblasti ekologije šuma, dok je korpus na srpskom jeziku sastavljen od članaka koje su napisali različiti autori iz dva izdanja časopisa Glasnik šumarskog fakulteta u Beogradu. Broj dosadašnjih studija koje su se bavile teorijskim statusom evidencijalnosti ili njenim opisom u srpskom jeziku nije veliki, što je predstavljalo dodatni razlog za izradu ove studije. Opis evidencijalnosti je načinjen pomoću primera iz tekstova na srpskom i engleskom jeziku, dok je posebna pažnja posvećena određenim prilozima, glagolima percepcije i nekim evidencijalnim konstrukcijama. Nalazi i opisi evidencijalnosti su predstavljeni komparativno, a ustanovljeno je da ova dva jezika generalno izražavaju evidencijalnost sličnim sredstvima. Opisane su neke interesantne konstrukcije i razlike u upotrebi markera evidencijalnosti, kao što su, na primer, dvoslojna evidencijalnost u engleskom jeziku i evidencijalne konstrukcije sa glagolom moći i glagolima kognicije u srpskom jeziku. Utvrđena svrha ovih konstrukcija je ograđivanje, kao jedna od tipičnih karakteristika akademskog diskursa. Još jedna odlika tekstova na srpskom je niz glagola percepcije, dok se nulta evidencijalnost javila u samo jednom primeru u korpusu tekstova na engleskom jeziku. Ovo istraživanje sugeriše da se ista jezička sredstva mogu upotrebiti kao marker evidencijalnosti i epistemičke modalnosti, čiji stepen epistemičke evaluacije varira u zavisnosti od tipa izvora informacije i konkretnog markera evidencijal- 
nosti koji je upotrebljen. Dok se epistemička komponenta u evidencijalima smatra fakultativnom, njen stepen se kreće duž gradijenta. Iako evidencijalnost i epistemička modalnost pripadaju različitim semantičkim oblastima, pronađeno je da se često preklapaju. Ipak, predloženo je da se se granica između ove dve oblasti zadrži, uprkos čestom preklapanju u markerima, koji samo na prvi pogled deluju kao čisto evidencijalni.

Ključne reči: evidencijalnost, epistemička modalnost, akademski diskurs 